\title{
Contents volume 83
}

Volume $83 / 1$

Reservoir characteristics of intracontinental carbonate ramp deposits-Upper MuscheRalk,

Middle Triassic, NE Netherlands

C. Pöppelreiter, A. Simone \& G. Hoetz

A sporomorph ecogroup model for the northwest European Jurassic - Lower Cretaceous I:

concepts and framework

O.A. Abbink, A. Simone \& G. Hoetz

Marine Miocene deposits in the Maaseik well $49 \mathrm{~W} / 220$ in eastern Belgium: biostratigraphy

by means of various microfossil groups

H. Hooyberghs, K. Wouters \& D. Spiegler

Strontium (87Sr/86Sr) dating of marine shells from Pliocene and Pleistocene shallow marine

deposits in The Netherlands

H.S.M. Jansen, J. Huizer, J.W.A. Dijkmans \& J.E. van Hinte

Faults in the Asquempont area, southern Brabant Massif, Belgium

T.N. Debacker, A. Herbosch, J. Verbiers \& M. Sintubin

A new record of Clidastes (Squamata, Mosasauridae) from the Upper Campanian of the

Münster Basin (NW Germany)

C. Diedrich \& E.W.A. Mulder

Volume $83 / 2$

Editorial

Faults in the Asquempont area, southern Brabant Massif, Belgium

T.N. Debacker, A. Herbosch, J. Verniers \& M. Sintubin (reprinted article from vol. 83, No. 1)

A sporomorph ecogroup model for the Northwest European Jurassic - Lower Cretaceous II:

Application to an exploration well from the Dutch North Sea

O.A. Abbink, J.H.A. Van Konijnenburg-Van Cittert, C.J. Van der Zwan \& H. Visscher

The geometry and stratigraphic position of the Maassluis Formation (western Netherlands and southeastern North Sea)

H.S.M. Jansen, J. Huizer, J.W.A. Dijkmans, C. Mesdag \& J.E. van Hinte

Assessing the contamination risk of five pesticides in a phreatic aquifer based on microcosm experiments and transport modelling at Sint-Jansteen (Zeeland, the Netherlands)

I. Gaus \& K. Vande Casteele

Paleozoic and Mesosoic igneous activity in the Netherlands: a tectonomagmatic review

W. Sissingh

New subsurface temperature maps for the Tertiary Lower Rhine Basin and the adjacent

Variscan Basement - Germany, The Netherlands, Belgium

H. Karg, C. Bucker \& R. Schellschmidt

Geo(Im)pulse

The sand extraction potential of embedded land surface lowering in the Netherlands

M.J. van der Mealen, M.P.E. de Kleine, J.G. Veldkamp, C.W. Dubelaar \& H.S. Pietersen 
Volume $83 / 3$

Special issue: North Sea Paleogene. Symposium on the Paleogene Preparing for Modern Life and Climate'.

Leuven, Belgium, 25-30 August 2003,

Guest editor: $N$. Vandenberghe

Introduction

N. Vandenberghe

Stratigraphic architecture of the Upper Cretaceous and Cenozoic along the southern

border of the North Sea Basin in Belgium

N. Vandenberghe, S. Van Simaeys, E. Steurbaut, J.W.M. Jagt \& P. J. Felder

Pyritized diatoms: a good fossil marker in the Upper Paleocene-Lower Eocene sediments

from the Belgian and Dieppe-Hampshire Basins

Y. Van Eetvelde, C. Dupuis \& C. Cornet

A rapid clay-mineral change in the earliest Priabonian of the North Sea Basin?

R. Saeys, A. Verheyen \& N. Vandenberghe

Insectivores (Mammalia) from the earliest Oligocene (MP 21) of Belgium

R. Smith

Stable oxygen isotope record of the Eocene-Oligocene transition in the southern

North Sea Basin: positioning the Oi-1 event

E. De Man, L. Ivany \& N. Vandenberghe

Sea-level related molluscan plankton events (Gastropoda, Euthecosomata) during

the Rupelian (Early Oligocene) of the North Sea Basin

K. Gürs \& A.W. Janssen

Magnetostratigraphy and rock magnetism of the Boom Clay (Rupelian stratotype)

in Belgium

D. Lagrou, N. Vandenberghe, S. Van Simaeys \& J. Hus

Late Oligocene Warming Event in the southern North Sea Basin: benthic foraminifera

as paleotemperature proxies

E. De Man \& S. Van Simaeys

The Rupelian-Chattian boundary in the North Sea Basin and its calibration

to the international time-scale

S. Van Simaeys

Volume $83 / 4$

Rib fracture in Prognathodon saturator (Mosasauridae, Late Cretaceous)

A.S. Schulp, G.H.I.M. Walenkamp, P.A.M. Hofman, B.M. Rothschild \& J.W.M. Jagt

A new Ordovician astylospongiid sponge (Porifera) as an erratic from Baltica

F. Rhebergen

A southern North Sea Miocene dinoflagellate cyst zonation

D.K. Munsterman \& H. Brinkhuis

Geo(Im)pulse

A geophysical profile at the foot of the Dutch coastal dunes near the former outlet

of the 'Old Rhine'

A.C. Seijmonsbergen, D.T. Biewinga \& A.P. Pruissers

Errata 


\section{Netherlands Journal of Geosciences / Geologie en Mijnbouw}

\section{Scope}

Netherlands Journal of Geosciences / Geologie en Mijnbouw seeks to be the prime outlet for publication of geoscientific papers pertaining to the Netherlands and the North Sea region and relevant adjacent areas. Manuscripts on any geoscientific topic will be considered for publication, provided they comply with the regional focus of the journal and are of international interest and quality.

\section{Submission of manuscripts}

Manuscripts may be submitted to the Editorial Office. Manuscripts should be prepared in accordance with the 'instructions to authors' as summarized in every first issue of a volume; the instruction is also available upon request from the Editorial Office and on the journal's website (http:/www.nitg.tno.nl/eng/products/pub/njg/ index.shtml). The author(s) of manuscripts submitted are responsible for obtaining clearance for publication from relevant parties including, if appropriate, permission to include copyright material.

\section{Subscription and distribution}

Netherlands Journal of Geosciences / Geologie en Mijnbouw is published quarterly and dispatched by surface post. The journal is distributed to members of the Royal Geological and Mining Society of the Netherlands (KNGMG) free of charge and to private and institutional subscribers. The rate for institutional subscribers for the year 2005 is EUR 285 / US\$ 310, an individual subscription is EUR 80 / US $\$ 88$. Subscriptions are handled by Drukkerij Giethoorn Ten Brink, Mrs. I. Germeraad-Huiskens, Eekhorstweg 1, 7942JC Meppel, The Netherlands (tel. +31 522855 213; fax +31 522855 100; e-mail: i.germeraad@gmgroep.nl).

All orders (including requests for back issues) and related business correspondence (including address changes for subscribers) should be addressed to Drukkerij Giethoorn Ten Brink.

\section{Abstracting and indexing}

Netherlands Journal of Geosciences / Geologie en Mijnbouw is indexed/abstracted in Biological Abstracts, Current Contents/Physical, Current Geographical Publications, Chemical \& Earth Sciences, Geological Abstracts, GeoArchive \& GeoTitles, Science Citation Index Expanded, ASCA, Cambridge Scientific Abstracts, INSPEC Information Services Petroleum Abstracts, Bibliography and Index of Geology, GeoRef, Geobase/ GeoAbstracts, Chemical Abstracts, The ISI Alerting Services.

\section{Copyright and photocopying}

(C) Stichting Netherlands fournal of Geosciences.

The journal (ISSN 0016-7746) is registered with the Copyright Clearance Center (CCC), 222 Rosewood Drive, Danvers, MA 01923, USA. Authorization to photocopy items for internal or personal use is granted by the Stichting Netherlands fournal of Geosciences, provided that the appropriate fee is paid directly to CCC. Prior to photocopying, please get permission online at the CCC wbsite (http://www.copyright.com) or call the CCC (+1 978750 8400), which can also be contacted for information about additional usage of material.

Requests for permission to reproduce material published in this journal for other publications should be addressed to the Editorial Office. 
Netherlands Journal of Geosciences / Geologie en Mijnbouw

Contents volume 83, No. 4 (December 2004)

Rib fracture in Prognathodon saturator (Mosasauridae, Late Cretaceous)

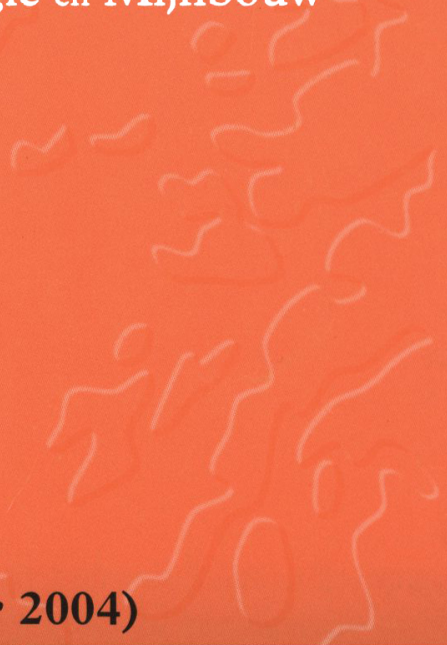

A.S. Schulp, G.H.I.M. Walenkamp, P.A.M. Hofman, B.M. Rothschild \& J.W.M. Jagt

A new Ordovician astylospongiid sponge (Porifera) as an erratic from Baltica

F. Rhebergen

A southern North Sea Miocene dinoflagellate cyst zonation

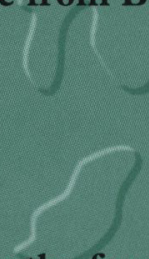

D.K. Munsterman \& H. Brinkhuis

Geo(Im)pulse

A geophysical profile at the foot of the Dutch coastal dunes near the former outlet of the 'Old Rhine'

A.C. Seijmonsbergen, D.T. Biewinga \& A.P. Pruissers

Forthcoming papers

Errata

Contents Volume 83
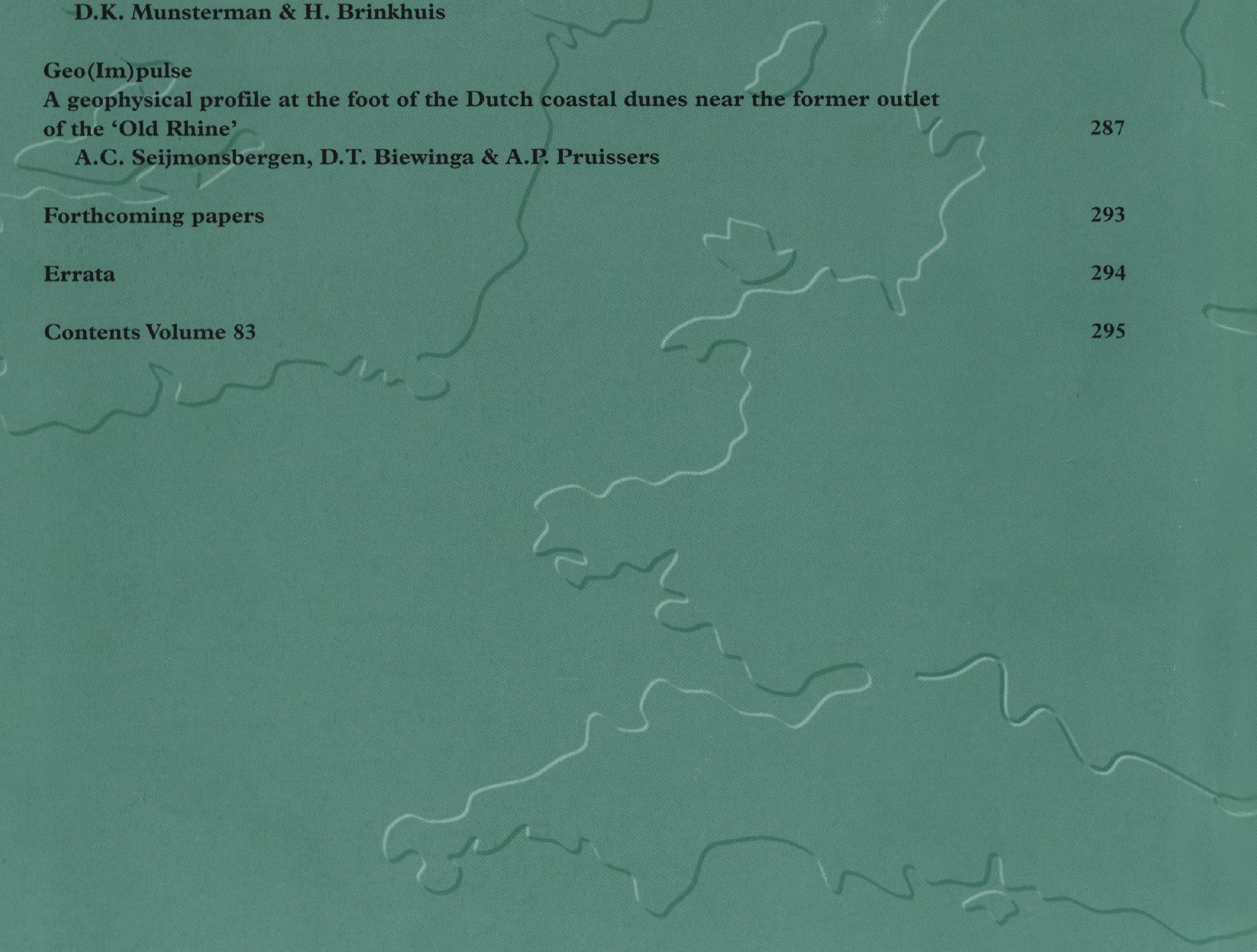